\title{
The European Union and UN Millennium Development Goals in Nigeria: A Study of the Micro Projects Programmes (MPPs) in the Niger Delta Region

NWAODU, Nnamdi 0. || EMIMA-EGBUMOKEI, Ngozi S. || ODEY, Stephen A.

\section{Abstract}

$\mathrm{T}$

he present Cotonou Accord was signed by the EU, 77, African Caribbean and Pacific (ACP) countries towards halving poverty as prescribed by the UN Declaration by 2015. The EU's intervention in the rural communities of the oil producing states of Nigeria (Niger Delta) clearly shows her commitment towards the above stated global drive for the eradication of poverty especially in the Third World. Bringing about the establishment of the Micro Project Programmes (MPP3, MPP6 and MPP9) for the nine states of the region between 1999 and 2012 and expended over €210 million on the programmes. Four years after the implementation of the programmes, arising questions include: to what extent did the EU-MPPs achieve the set goals of poverty reduction in the region? And how sustainable are the achievements of the programmes? Using ex post facto research design, it was found out that amidst numerous challenges the MPPs actually reduced the level of poverty in the region through the provision of over 20,000 micro projects to more than 4000 rural communities in the nine states it covered. It therefore recommended that similar programmes be initiated by all other international development agencies as to speed up the reduction of poverty in the UN targeted areas though behind the originally target period of 2015 . The study contends that an effective administrative institutional framework of the EU- MPPs should serve as model to other development agencies not only in Nigeria but across the developing economies of the world.

Keywords: UN Millennium Declaration, European Union, UN Millennium Development Goals (MDGs), Micro Project Programmes, Niger Delta region, Rural Poverty 


\section{INTRODUCTION}

Nature, on its own, does not provide man with all the required paraphernalia for his wellbeing and overall development. Therefore, the greatest preoccupation of man ever since creation has remained to adequately provide for himself what is lacking in nature for his maximum wellbeing. For this reason, all human institutions- governmental and nongovernmental are designed in conformity with this main task of man. Be that as it may, all human institutions perform actions that complement one another in this direction.

The rising poverty level in Africa is one challenge which humanity have long confronted without a clear victory. Today, all levels of government- national, regional and local together with non-governmental international development agencies have indeed orchestrated a synergy in this battle. The United Nations declaration of the Millennium Development Goals of fundamentally reducing the level of poverty across the developing world is one strategy, which is now embraced by all above institutions and agencies across the globe.

The EU has over the past five decades initiated development programme in different parts of Africa, Caribbean and Pacific, ACP via the Yaoundé I \& II conventions, Lome I, II, III, and IV conventions among others. She signed the present Cotonou Accord in the year 2000 between herself and 77 African, Caribbean and Pacific, ACP, states as part of her response to meeting the UN declarations on persisting poverty as expressed in the Millenniums Development Goals (MDGs) of cutting poverty into halve by the year 2015 . Specifically, the EU's more than a decade's development intervention in the rural communities of the oil producing states (Niger Delta) of Nigeria was a clear show of her commitment towards the global drive for the eradication of poverty in Third World countries. Within this period, she initiated and implemented the three phased Micro Project Programmes, MPP3 (2000-2004), MPP6 (2004-2008) and MPP9 (2008-2012) for the nine states of the region between years 2000 and 2012 and expended over $€ 210$ million in the programme.

This UN charted EU intervention is indeed predicated on the World Bank's Basic Needs theoretical perspective of the 1970's which states that the aim of development policies in individual countries should be to meet the basic needs of the entire population including the rural dwellers (Thrirlwall, 1994:9). It holds further that certain basic consumption goods such as food, clothing and shelter are to be met by everyone as entitlement and that such basic services as education, health services and clean water are necessarily to be made 
available, and that there is the right for people to participate in making and implementing decisions that affect their development.

Inherent in the Basic Needs approach to development are the attractions of equity and social justice because the basic needs, which must be met, have to affect the entire population concerned equally. This development principle was duly imbued into the EUMPPs process of implementing all its range of projects. From the school blocks, health centres, water and sanitation projects, oil and palm kernel processing plants, market stalls, culverts among others, the processes were designed in conformity to positively bring about an egalitarian society; impacting equally on both the poor and the minority groups in the society (Nwaodu, 2010).

The completion of the last phase of these EU-MPPs is now about four years and arising concerns include: to what extent did EU three Micro Project Programmes achieve the set goal? The general objective of this paper is to find out the extent the EU-MPPs contributed to achieving the UN declared poverty reduction by 2015 in the rural communities of the Niger Delta region of Nigeria. The study is to find out the extent the EU-MPPs rural development objectives (expressed in the words poverty eradication as enshrined in the Cotonou Agreement) have been achieved after four years of completion of the project implementation programme in the region.

In specific terms, the study is designed to find out, the extent the implementation of MPPs in the states reduced poverty or simply improved the standard of living of the people of those communities that benefited from the programme; as well as to find out what kind of administrative designs used in the implementation and the impact of such special designs in the achievements and sustainability of the MPPs in the area.

Using ex post facto research design, the study will also set out to analyse the implementation procedure of MPPs; examine the achievements and failures of the programmes, and recommend proper development measures that would accelerate over all development of the Niger Delta area in particular, and Nigeria in general.

\section{CONCEPTUALISING DEVELOPMENT COOPERATION}

Development cooperation is in the field of International Economic Relations and administration. It cuts across trade, finance, investment, technical assistance or cooperation's among nations and administration of sort. It came into existence with the introduction of the United Nations Charter, which promised to promote social and 
economic progress, better standard of living of all people, using international machinery (Nnamdi, 2011). Much of development cooperation today refers development assistance, development aid, technical and international or foreign aid or overseas aid, etc., which include permanent contact and discussion of possibilities to improve the development of third world partners and extend economic relationship between the third world countries and the industrialized countries (Kramer u/d: 95). Development cooperation in Kramer's view is confined to development assistance, financial and technical assistance, which alleviates poverty in the short run. Kramer believed that the major aim of development cooperation should be to improve the economic development of less developed countries (LDC).

Development cooperation plays important role in giving ideas on how countries could achieve economic development. It is synonymous with development aid that comes from the western industrialized countries to the less developed ones. Occasionally, a little percentage of the aid comes from the developing countries to the pull of a multi-lateral agency aid program as a contribution. It could be a bi-lateral aid (aid given from one country directly to another) or multi-lateral (aid given by the donor country to international agencies-like World Bank, European Union, etc.), which will in turn distribute these among the targeted benefiting countries (Griffin and McKinley, 1994:2).

Development cooperation as aid/assistance could be classified into various agencies like-the European Union (EU), World Bank (WB), and United Nations Development Program (UNDP), the International Fund for Agricultural Development (IFAD), United States Agency for International Development (USAID) and so on. Over the years, Britain and some other commonwealth countries have used these medium to give various types of assistance like financial cooperation, grants, loans, humanitarian aids, food aid, program aid, etc., to African and other third world countries. Development Cooperation between the EEC and ACP countries where the EEC countries is the principal trading partner of the ACP countries is about the widest known development cooperation/administration in human history. Within this framework, EEC countries on the average absorb 50percent of the total exports and provide about 58percent of the imports (Nnamdi, 2011).

Trade cooperation came into existence through the agreement and signing of letters on Lome convention, as the government of both the EEC and the ACP countries undertook to adopt a unilateral procedure that would permit trade relationship between the two countries. The Lome conventions were series of cooperation agreement guiding the 
relationship, aid and trade contract between then 15 EEC (European) countries on one hand, and 70 ACP states on the other hand on trade and aid provision. The Lome conventions, which had a life span of 25years, with regular amendments, were the backbone of the economic cooperation between the ACP and EEC countries. These conventions defined the development cooperation agreement between Nigeria and European community; it introduced Nigeria as a major player in the EU-ACP relations (Nnamdi, 2011)

\section{EVOLUTION OF EU-NIGERIA COOPERATION/ADMINISTRATION AGAINST POVERTY}

The cooperation between European Union (formerly EEC) and Nigeria could be traced back to both the un-ratified 1966 Nigeria-EEC treaty and the first Lome convention, which had Nigeria and 45 other African Caribbean and Pacific (ACP) groups of states as its members Twitchett C.C, (1981). Before the Lome convention, Nigeria's attempt to enter into cooperation with EEC through the un-ratified Lagos agreement was frustrated by some fundamental dissatisfaction. First and foremost, Nigeria was not satisfied with the concept of 'association' that formed the basis of the EEC African states relations, secondly, Nigeria did not like the break in diplomatic relations with France, over France detonation of a nuclear device in the Sahara Desert at that time... thirdly, Nigeria was not happy that Britain (her former colonial master), failed to join the common market due to numerous problems that she (Britain) was confronted with then Uweche R. (ed.), (1981). The interest of each member country or organization (including EU) in any international partnership is to score points that will be beneficial to her. The European Union agreement with Africa (African Caribbean and Pacific countries) known as ACP-EU was signed in Cotonou in the year 2000 and it replaced the serial Lome Conventions the last of which was to be concluded The Point (2000). 
The principle that guided the EU-ACP partnership was 'Fundamental Unity of Africa' and her right to meaningful and sustainable development (Nnamdi, 2011). The cooperation ensured that all the relevant international agreements and declarations were implemented for sustainable development in the African countries. Some of the important basis and objectives of ACP-EU cooperation was to achieve the Millennium Development Goals (MDGs), by developing a global partnership for sustainable economic development in the partnering countries (Nigeria being one of them), reduction and eradication of extreme poverty and hunger through supporting sustainable economic and environment development in the ACP region and its integration into the world economy. Equity was put at the centre of the action by giving priority to defending the interest of the most disadvantaged countries and the poorest section of their population (Adebayo, 2002).

The Lome conventions were series of cooperation agreement guiding the relationship, aid and trade contacts between EEC and ACP states. They were the backbones for economic cooperation between the ACP and EU countries, and represented the policies of some of the developed western powers towards the less developed countries. It was these conventions that defined the development cooperation agreement between Nigeria and the European community. Lome conventions expired ultimately after 25years and the Cotonou Partnership Agreement between the European Union (EU) and 77 African, the Caribbean and the Pacific Island, succeeded it. One of the central objectives of the Cotonou Agreement as expressed in its (Article 19) was to contribute to sustainable development as it gradually integrates the ACP countries into the world economy. Cotonou Partnership Agreement was a landmark agreement; it was on this platform that the European Union Micro Project Programs took its root. Nigerian government and the European Union (EU) signed the financial agreement for Micro-project program in October 2001, with a funding of 42 million Euro which was about 53 million dollars, for micro projects in the most populous African countries (Nnamdi, 2011).

\section{EU MICRO PROJECT PROGRAMS IN NIGERIA (PRE-1999 ERA)}

From the outset, the Lome conventions provided for rural development in the ACP states through its emphasis on micro projects. The entire (Protocol no.2) of the first Lome Convention death with micro projects from articles 14-17. However, the conventional provisions for rural development notwithstanding, much of the expected allocation of resources for the micro projects started coming from Lome II. (Twitchett 1981; Sanu and 
Onwuka (1997) and Europe South Dialogue, 1988). Further observed by Twitchett (1981), the special emphasis placed on agricultural co-operation in Lome II is new, although the EDF under both the earlier Yaoundé and Lome regime, in fact, allocated the bulk of its aid to rural production and infrastructural projects designed to assist rural development,

The above views were reiterated by Europe-South Dialogue (1988) when it remarked that Lome II already represented an increase in the proportion of funds channelled to the rural sector. Noting further than if micro-projects are included, the sector absorbed $44.2 \%$ of national allocations (as distinct from regional project funds), compared to $34.8 \%$ under Lome I.

It was observed that the Lome II altered the big project approach by encouraging involvement of local communities in an increasing number of integrated rural projects. In this new dimension, local peasant farmers further defined the aims of these projects, took part in the work and managed them. Micro-projects were also on the increase and nongovernmental organizations got more support. There was also increasing emphasis on support for food crops -which look more than two - third of 5th EDF rural development allocations and less on cash crops.

Under Lome III, Sanu and Onwuka (1997) observed that community aid emphasized rural development, industrialization, energy and mining underscoring that under 4th and 5th EDF, about ECU 34 million, about 5 percent of the supply, sanitation and urban development. Together with Europe-South Dialogue (1986) Sanu and Onwuka reiterated that:

Lome $\mathrm{HI}$ placed the rural population at the centre of the development process and took rural development in its widest sense noting that it emphasized incentives at all levels to increase production and improve marketing (price policy, land reforms, improved agricultural techniques, supply of inputs, restructuring of marking channels maintenance, infrastructure repairs, etc (Europe-South Dialogue 1986:31).

Sectorial rural development strategies also included measures concerning education, health, nutrition, etc., with the aim of improving living conditions in the countryside. By means of those strategies the ACP states aim to increase their self-sufficiency and food security. In a similar manner, the Economic commission for Africa TRID TEAM (2008:10) added that Lome III (1985-1990) had EDF priorities increased in the areas of infrastructure 
and rural development. Note: the first EDF was set up in 1958 and it has been replenished every 5 years ever since.

According to TRID TEAM, EDF funding was then raised to 7.5 billion ECUs. Lome IV though covering the long period between (1990-2000) was observed by Qng'wen (2007) and ECA trid team (2008) as not differing fundamentally from Lome V. In his words, the only new innovations were the incorporation for the first time, of human rights (Art.5), heavy dose of structural adjustment policies, and the idea of decentralized cooperation. The Cotonou Partnership Agreement which replaced Lome iv and covering the period of 25 years with intermediate reviews is somehow revolutionary Vis-a-Vis the precede conventions. Its overarching objective as Ong'wen remarks is stated as that of reduction with a view to eventual eradication, of poverty while contributing to sustainable development and to gradual integration of ACP countries into the world economy (Ong'wen 2008:8).

\subsection{A Tabular Summary of how EU Assisted Nigeria before Cooperation Suspension in}

1995

\begin{tabular}{|c|c|}
\hline 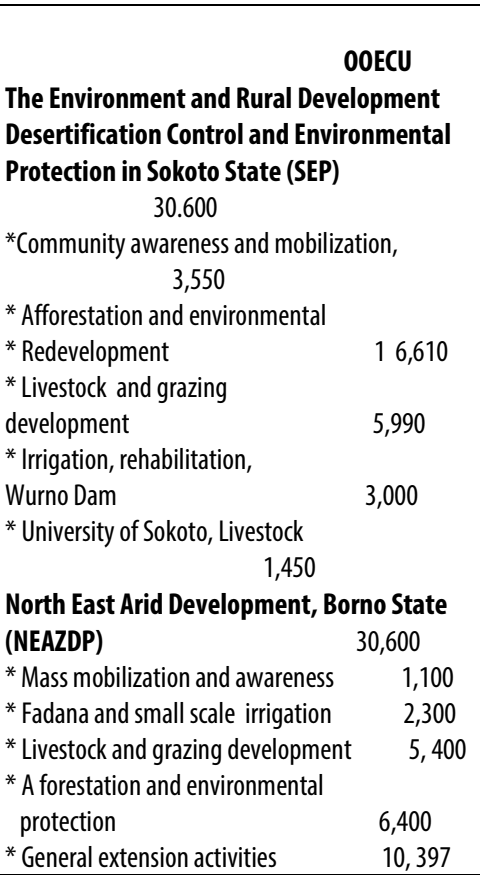 & 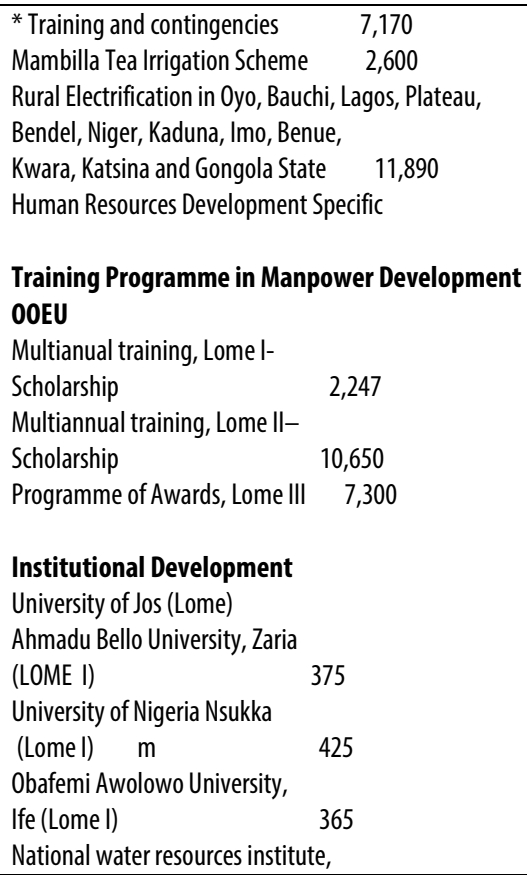 \\
\hline
\end{tabular}


The EU and UN Millennium Development Goals in Nigeria: A Study of the MMPs 467

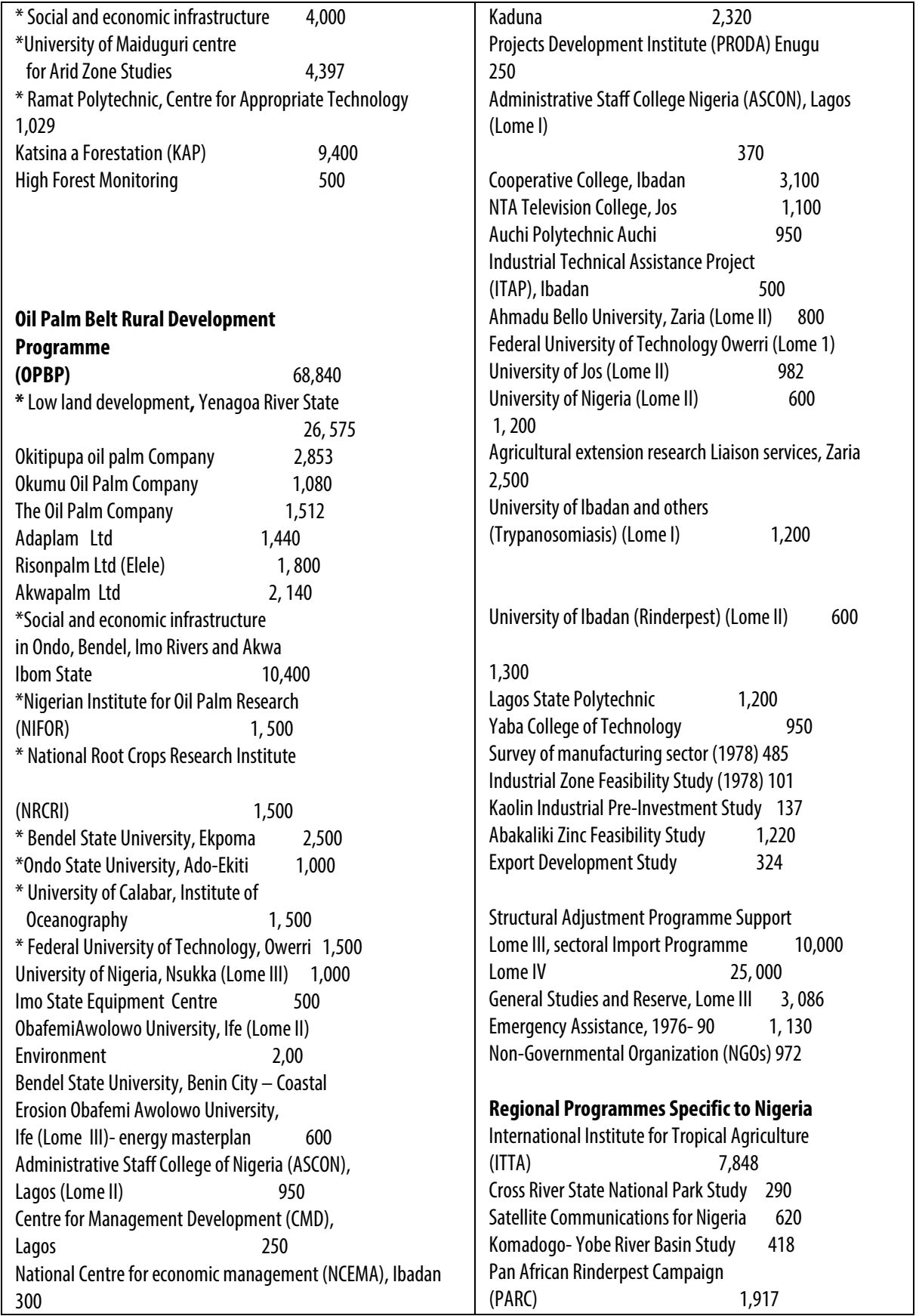




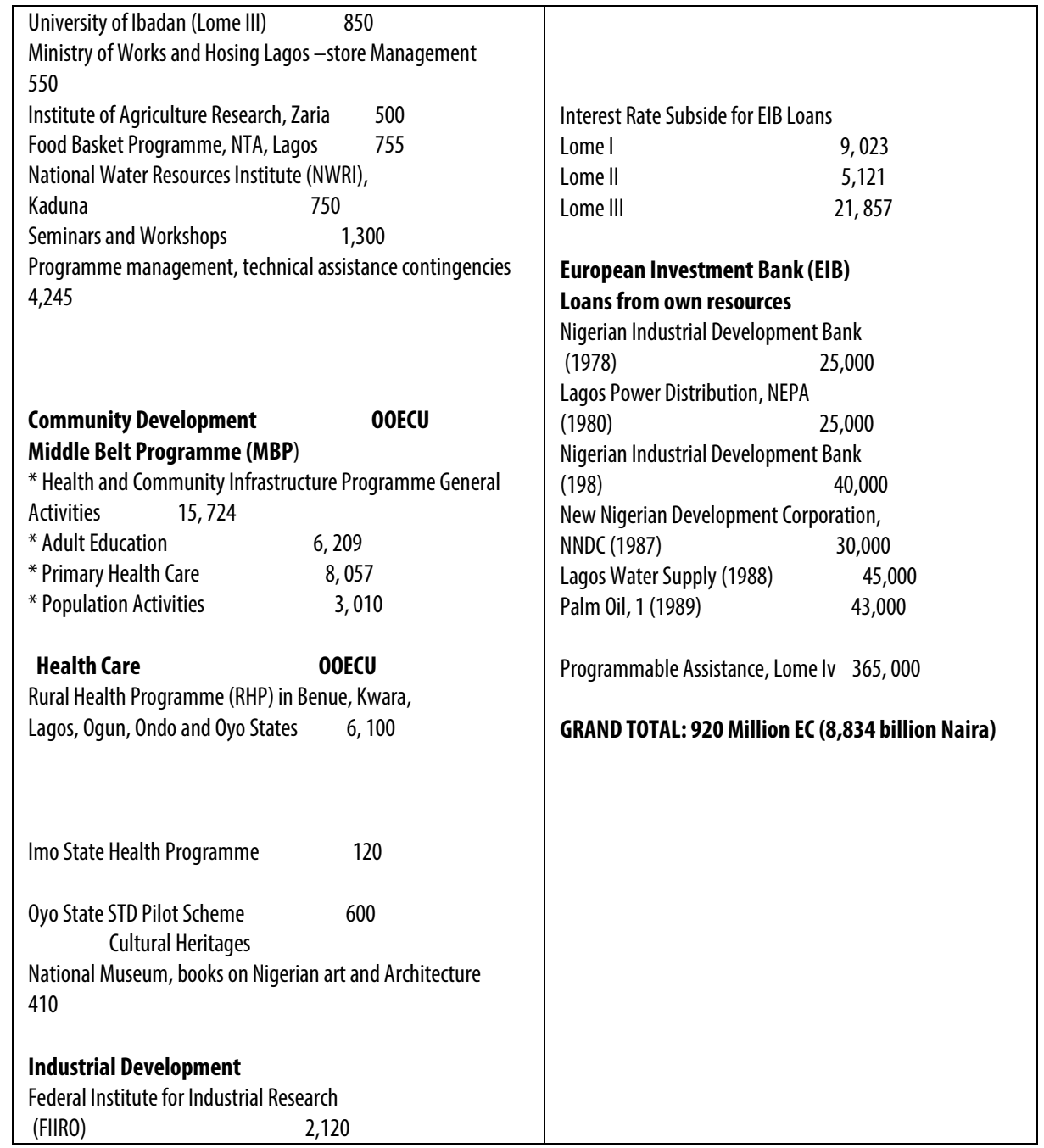

Source: NewsWatch December 4, 1995: 10-11

Table 1.1 above clearly reveals that EU interventions in Nigeria through the implementation of micro projects have been critical in not only institutional development but also increased standard of living rural communities across the country. It is obvious from the table that these interventions have been there for quite some time in the life of the country and that they cut across many sectors and sub-sectors of the nation's economy at the micro level. 
It will be noticed from the subsequent sub-sections of the paper that over time the EU has rather increased the scope, volume and amount of her commitments in Nigeria.

\section{EU MICRO PROJECT PROGRAMS IN NIGERIA (POST-1999 ERA)}

The EU development administration in Nigeria took a fresh dimension, character, and pattern with the latter's ratification of the Cotonou Partnership Accord in the year 2000. This Accord which replaced the Lome Convention presented a new platform for the EU's development administration in not only Nigeria but in the rest of the ACP states.

In this new pattern of development cooperation, Nigeria and the EU agreed to imbue anti-corruption measures into the development administration machineries for the Niger Delta region. In addition to the proper utilization of the mapped out European Union Development Fund the strategy was also designed to support Nigeria's own efforts to use its own funding better through a well-orchestrated development administration institution. This was as against former arrangements of organizing only stand-alone projects isolated from Nigerian structures.

It is important to note that in addition to the micro projects programmes (EU Development Administration Agency) in the Niger Delta which this paper is going to evaluate, the EU-Nigeria cooperation is also manifest in the following other programmes:

1) The Support Good Government and Water Sanitation in six states of Abia, Cross Rivers, Gombe, Kebbi, Osun and plateau with a total of $£ 144 m$ (A25) projected.

2) Reducing Child Mortality by strengthening immunization with $£ 44$ million projected for it. It is aimed at eradicating polio.

3) Census Support Project aimed at encouraging Nigeria to organize a successful census in 2005. This gulped about $£ 113.5 m$ (i.e., 20 Billion Naira).

4) Small Town Water Supply and Sanitation Programme aimed at supporting small Towns with Water Supply and Sanitation. The project, with a budget of $£ 15 \mathrm{~m}$ (about A2.6 billion) covers three states of Adamawa, Delta and Ekiti.

Other projects of the European Union in Nigeria include the National/State Assemblies, Human Rights, Prisons Reforms, Economic Management and capacity building etc. In sum the EU Economic Development Fund EDF for Nigeria between 2002 and 2007 is estimated to $£ 650$ (i.e., an equivalence of over 115 billion Naira). 
Micro projects are one of the instrument EU-ACP development cooperation, in response to the needs of local communities. Nigeria has been involved in the signing of one form of development cooperation agreement or the other with the West and the European Union, for the past three decades, all in the bid to wriggle out of poverty and underdevelopment. At times, Nigeria as an independent country negotiates and signs these agreements together with other independent ACP states, but more often than not, she negotiates and signs alone. The European Union Micro Projects - MPP3, MPP6 and MPP9 are typical examples of such agreement that Nigeria entered into alone with EU (Nnamdi, 2011). European Union assistance to African countries was based on the Union's consensus on "Development"-an agreement to assist the African countries in every sphere of development initiatives. Its set out principles, values and objectives are in line with the United Nations Development Goals (MDGs), which is poverty eradication and sustainable development. EU has particularly continued to assist Nigeria in different areas and many ways, but in spite of all the efforts and strategies put in by the EU; Nigeria (especially the Niger Delta region) is still backward and almost in the dark as far as development is concerned. It is in the bid to bridge this gap that the European Union (EU)-Nigeria Cooperation and Rural Development in Nigeria - EU Micro Project Programs, came into existence in the names of MPP3 (Micro Projects Program in three states), MPP6 (Micro Projects Program in six states) and MPP9 (Micro Projects Program in nine states) all in the Niger Delta area of Delta state in Nigeria. These are European Union funded programs, implemented through the National Planning Office at the Presidency in Abuja, as a result of the height of violence, hostility, armed conflict, militancy and other social vices in the Niger Delta region in the late 1990s by the people in the area, who felt that they have suffered long years of abject neglect and deprivation by both governments and transnational co operations, that were involved in oil exploration and exploitation activities in their land. The rancour threatened the smooth operation of the multinationals, as most of their oil installations were vandalized and left desolate. In 2001, the European Union nations as mother countries to the multinational oil exploration co operations in the Niger Delta region came through a political agency-the European Union EU), to reduce the tension and create conducive atmosphere for business. The program began as a pilot program for three states in the Niger Delta area of Nigeria namely - Bayelsa, Delta and Rivers, with a management head office in Port Harcourt and regional offices for each state at Yenegoa, Asaba and Port Harcourt (Micro Project Programs, 2003). 
Micro project program is a, multi-annual development cooperation program in response to the needs of the local communities. One of its major objectives is the development of the people's economic and social situation in line with the need of the communities. Micro projects are integrated rural socio-economic development programs, funded by the commission of European communities in cooperation with the rural communities. It was designed to be undertaken at the initiatives of the local communities, which have to contribute to their implementation in terms of service, cash or kind. In 1999, the European Commission (EC) and the Nigerian Government agreed to prioritize the Niger Delta issues. Two micro projects programs-MPP3 (Micro Project Programs in three states) and MPP6 (Micro Project Programs in six states) all in Niger Delta region of Nigeria were introduced in 2001 and 2004 respectively. MPP9 (Micro Project Programs in Nine states in Niger Delta region), was the third micro projects program that was later introduced (Midterm Review of Micro Projects Programs in Niger Delta, 2006:1). The overall objectives of the micro projects program were to improve the living standards of people in the poor communities of the region, reduce tension and mitigate the causes of conflict in the area, thereby contributing to poverty reduction and eradication of extreme hunger in the region. For example, the MPP3 (Micro Project program me in 3 Niger Delta States - Bayelsa, Delta and Rivers), did well in assisting in the implementation of basic infrastructure and support of income generation activities in the area; the MPP6 (Micro Project Programs in six of Niger Delta states - Abia, Akwa-Ibom, Cross Rivers, Edo, Imo and Ondo), did same as MPP3 but had a better result than the MPP3, while MPP9 (Micro Project Programs in nine states of Niger Delta region-Abia, Akwa-Ibom, Bayelsa, Cross Rivers, Delta, Edo, Imo, Ondo and Rivers),provided models to support reforms towards transparency and participation by states and local government areas (Micro Projects Program in Nine States, MPP9,(2014). The EU-MPP3 and MPP6 came through a document titled 'communication', it was issued by EU in April 2000. In the document, the MPP3 defined poverty reduction as its central objective; it went further to select priority area that EU development activities should concentrate on in the Niger Delta region, while EU-MPP6 and EU-MPP9, set their goals towards contributing to bridging the gap between the rich and the poor in the oil producing states (the Niger Delta region), through sustainable development program, as it supported income generating activities. Niger Delta is the main oil producing area in Nigeria; it provides most of the 95percent of government revenues deriving from crude 
oil production. However, many communities in the area are amongst the least developed in the country (MPP6, 2008:1).

In this study, it was discovered that from 1999 to 2012 the EU implemented over 20,000 micro projects to more than 4000 rural communities in the nine states it covered. This was in the $b$ amidst numerous development challenges in the area.

The table below summarizes the EDF allocation to the different sectors of intervention in a state of the Niger Delta representing the other states as variation in fund allocation to states in the three different phases was insignificant.

Table 1:2: Allocation of EDF Micro-Projects in the NIGER DELTA according to sectors (MPP62002-2008)

\begin{tabular}{|c|c|c|c|c|l|l|l|}
\hline STATE & $\begin{array}{l}\text { Water } \\
\text { Sanitation }\end{array}$ & $\begin{array}{l}\text { Transport } \\
\text { Infrastructure }\end{array}$ & $\begin{array}{l}\text { Health } \\
\text { Centres }\end{array}$ & $\begin{array}{l}\text { School } \\
\text { Blocks }\end{array}$ & $\begin{array}{l}\text { Income } \\
\text { Generation }\end{array}$ & $\begin{array}{l}\text { Civic } \\
\text { Centre \& } \\
\text { others }\end{array}$ & Total \\
\hline Imo & 224,260, & 33,510, & $252,615,7$ & $177,862,0$ & $146,929,5$ & $48,976,5$ & $884,155,0$ \\
897.93 & 249.12 & 24.10 & 91.46 & 53.81 & 17,94 & 34.35 \\
\hline
\end{tabular}

Source: Adapted from (2008) Micro - Projects Compendium, Abuja ABG Multimedia Services Limited.

The implication of this is that not all the communities were expected to benefit from this first phase of the EU Micro projects in state region.

The content of the above table was not fully replicated in MPP9 which covered the period between 2008 and 2012 because it was barely complementary to MPP6. It had less budgetary allocation of fund from the European Development Fund and as such its impact level was less when compared with its preceding programme.

\section{Analysis of Administrative Framework of EU-MPPs in the Niger Delta}

It is fundamental to note the EU-MPPs had a development administration institutional structure set up in the post Lome Convention's era when enough experience abound as to why strong institutions are direly needed for any development administration agency to succeed in Nigeria. To the extent of the above experience the MPPs had imbued development administration mechanisms aimed at overcoming the observed impediments 
such as bureaucratic bottlenecks and multifarious institutional corruption among other impediments which abound in the Nigerian system - frustrating any development administration/intervention agency in the past from maximal goal attainment (Nwaodu, 2010).

This study found out that the MPPs had distinct structures of administrative institutions in their well-designed organisational setting. For example, their project Implementation procedure were individually-based and implemented according to three party agreements, where parties' commitments were as described below. This distinguished itself from the conventional approaches by Federal, states and local governments where the project is packaged by the government and delivered to the people with little or no input from them; and little or no measures put in place for the sustainability of the projects.

According to the implementation procedure the MPPs office of the EU played the following roles: funding with European Development Fund of not more than $75 \%$ of the project cost, assisting partner organization and community with technical supervision of project implementation, building capacity of both parties through on-the-job and scheduled training, supporting partner organization tasks with a sum of NGN 250,000 per project.

\section{Partner Organization - CSO}

The partner organization performed the following roles: Contributing to project implementation with own funds, identifying community specific need and priorities, preparing project proposal, setting up Project Management Committee, keeping all records related to the project, executing project purchases, building community capacity, monitoring the project up to one year after completion, keeping copies of project documents for three years after project completion, and participating in any requested audit.

Community: the benefiting community on the other hand played the following roles: contributing at least $25 \%$ of project cost in kind, labour or cash, setting up Project Management Committees, endorsing project purchases, keeping projects supplies purchases and adhering to the project sustainability plan, etc. 


\section{Development of prototypes, Project selection and Monitoring Arrangement}

Distinctions in the administration of these programs were seen in the development of prototypes of micro-projects, Project selection and Monitoring Arrangement.

In this case the Micro Project Management Unit MMU proposed designs not limited to the lowest possible cost but based on a best economical compromise between safety, uniformity, quality (duration) and conformity to existing State specifications. This was adopted around the programmes and it served to save the management possibilities of cost inflation and other such sharp practices that had negative effects on development programs in Nigeria in the past. For example, there were prototypes for school buildings, health-care centres, water sanitation projects, etc.

Project selection and Monitoring Arrangement. This was another area of administrative distinction in the EU MPPs scheme of things in the Niger Delta which ensures that the Monitoring Arrangements were alive and active all through the life of each projects.

The MPPs projects selection arrangements took into consideration some conditions before granting support to proposed projects. Indeed, its final choice of project depended on a choice made through the active participation of the women and youth groups among other special interests in the communities. The peoples' participation at all levels of project cycle guaranteed for provision of infrastructure best needed by the people.

In the case of project monitoring, representatives from all the interest groups in the society were made to constitute committees for the monitoring of the projects after completion. This monitoring arrangements follow -up development on the projects.

The development of workable monitoring system is at state level and by a reporting system following a standard defined by the EU Micro Project Management Unit MMU, State Monitoring Organisation SMOs. Members of a technical committee ensures monitoring standards that meet basic information needs by visiting projects sites and assessing State Monitoring Organisation and MMU databases. All monitoring activities were developed with close reference to Civil Society Organisations and Community Based Organisation which were as well involved in field operations and to the development of community-based participatory project monitoring mechanisms.

Reviews/Evaluation/Audits: the EU-MPPs had in-built independent evaluation and midterm review procedures that is carried out before the $24^{\text {th }}$ month after programme start. An evaluation was also carried out at the end of programme. Independent auditing 
companies were contracted to conduct financial audit every two or three months, including inspections of randomly selected sites.

\section{Conclusion}

The paradox of persisting poverty in the oil producing states of Nigeria (Niger Delta region) has remained a major concern to national and international governmental and nongovernmental agencies. With its triple-barrelled rural development intervention programme, the EU-MPP3, MPP6 and MPP9 (2000-2002), (2003-2008) and (2008-2012) respectively. The EU delegation to Nigeria asserted that the programmes were put in place to help Nigeria attain the Millennium Development Goal of reducing poverty level to half by the year 2015. The two-fold concern of this paper included assessing the goal achievement and the administrative mechanism of the EU's MPPs. It therefore concerned itself with finding out whether the said projects were completed and functional. Secondly, whether the EU through the implementation of these multi-variant rural community based micro-projects programme in the region, achieved objective of reducing poverty by half in 2015. More so, as to how the administrative structure of the MPPs fared during the span.

An ex post facto research design was adopted in the execution of the study, and it combined historical and descriptive methods in which it collected and analysed data using a combination of observation, interviews, and review of existing relevant literature. It therefore $x$-rayed the various impediments that abound in the process of project implementations in the rural areas. The study concluded that EU MPPs made significant impact in reducing the high poverty level in the area. It was able to manage successfully such persisting development challenges as political domination and communal conflicts in the area, bureaucratic impediments and administrative bottlenecks/red-tapism, command hierarchical structure, corruption among others. Which have had long standing in rural development in cronyism, nepotism, using the above described special administrative model.

\section{Recommendations}

The EU-MPP6 model of projects implementation which is enshrined with all manner of transparency, administrative discipline and effective people participation at all levels of project initiation, planning, implementation and maintenance should be adopted by the 
Federal, state and local government bureaucracies responsible for rural development in the country. That similar programmes be initiated by all other international development agencies as to speed up the reduction of poverty in the UN targeted areas though behind the originally target period of 2015. Again the very effective administrative institutional framework of the EU- MPPs should serve as model to the other development economies.

That further development of the various administrations at various level of national, state and local government focusing mainly on EU0-MPPs structure could reduce communal classes and conflicts which usually frustrate development programmes, and enhance the administration of rural development in the country.

All tiers of government should allocate more funds to rural development and ensure that such funds are adequately utilized through development partners towards meeting the basic needs of the people.

The local governments should step up efforts in the mobilization of the local people towards the development of their areas. This should be done through matching grants readily available to those rural projects that are essential to the well-being of the people.

Manpower Development: the various tiers of government, the non- governmental agencies and the donor agencies should step efforts in manpower development especially as it relates to the maintenance of the rural development projects provided for the communities. This more important when the projects require semi-skilled manpower for its management, the will guarantee for efficiency and effectiveness in the management of the projects.

The study therefore concludes that the EU intervention model is an avalanche towards the achievement of halving poverty in a manner that ensures transparency, accountability and participation. This study argues that these tripartite alliances are essential pillars in the development discourse in terms of participatory development.

\section{List of References}

- Adebayo A. (2002), Principles and Practice of Public Administration in Nigeria, Ibadan: Spectrum Books Ltd. 
- Adike, A.A. (1992). "Rural development in Nigeria: an overview", in Olise, S.O. and Obiukwu J. I., (1991). Rural development in Nigeria, dynamics and constraints, Awka, Mekslink Publishers, Nigeria.

- African Network for Environment and Economic Justice, ANEEJ. (2004) Oil of Poverty in Niger Delta, @www.aneej.com

- $\quad$ Asukwo, P. E., (1989), Financing Rural Development in Nigeria, Owerri, Karto Press.

- Annan K. (2000). 'The Role of the UN in the $21^{\text {st }}$ Century; Freedom from Want', A Report presented to the Millennium Summit of the Heads of States and Governments convoked by the UN October 2000 .

- Babarinde, A.O. (1994). The Lome Conventions and Development. An empirical assessment, Aldershot; Avebury.

- Baraldi A. (2005). 'EU funds 8.3 million dollar projects in Nigeria's Niger Delta', People's Daily Online 22 September 2005.V'Beyond Lome IV, Exploring Options for Future ACP-EU Cooperation," (1996). European Centre for Development Policy Management, Oct.

- DRI (Development Research Insights). (1998). Private good = public gain? Has ethical pressure squared the circle? Development Research Insights, 28.

- Eatwell, J. (1996). International financial liberalization: the impact on world development. Office of Development Studies, United Nations Development Program, New York, NY, USA. Discussion Paper Series No. 12.

- $\quad$ ECA-Trid Team (2008), European Commission.

- E-courier, ACP-EU, April 10 (2006), www.mpp6.org

- Ekpe, A. E., \& Awofeso, O. (1998). "Policies strategies and constraints to rural development in Nigeria (1976-1996)," In O.O. Okereke, (Ed.), (1998), Development in Nigeria Calabar: Wusen Press.

- Ekpo, U. (2004). The Niger Delta and Oil Politics, Lagos: International EnerguA Communications Ltd.

- European Commission (2002). Bilateral Trade Relations, ACP Countries (77), at http://europa.eu.int/comm/trade/acp.htm

- Europe-South Dialogue, (1980). Official publication of the European Community, Luxembourg.

- Federal office of Statistics (1998) Poverty Profile in Nigeria 1980-1996 
- Federal Republic of Nigeria (2000). NDDC Act. Abuja: Government Printer.

- Gordon, L. (1977). Foreword. In From Marshall Plan to global interdependence: new challenges for the industrialized nations, Organisation for Economic Co-operation and Development, Paris, France.

- Griffin, K and McKinley, T. (1994) A New framework for development cooperation, New York. United Nations Development Programme, Human Report Office.

- Hoagland, J. (1997). Why the Marshall Plan worked, The Washington Post, 8 Jun 1997.

- Ibaba, S. I. (2001). Understanding the Niger Delta Crisis. Port Harcourt. Jivac Publishing Company.

- Idaraesit, I.U. (2007). "The Impact of development Aids on Rural Economy in Nigeria: A Study of UNDP Projects in Akwa-lbom State." M.Sc. thesis, Department of Sociology, University of Calabar.

- Idode J.B. (1989). Rural development and bureaucracy in Nigeria, Longman Nigeria Ltd.

- IDRC (International Development Research Centre). (1991), Empowerment through knowledge: the strategy of the International Development Research Centre. IDRC, Ottawa, ON, Canada.

- IDS (Institute of Development Studies), (1998).CAP reforms: will developing countries benefit? IDS, Sussex, UK, Policy Briefing Issue No. 11, Feb.

- Institute for Food and Agriculture Development (IFAD) (2006) Rural Poverty in Nigeria.

- Igbozuirike, U.M.; Okpara, E.E. and Awuzie, U.A. (eds.) (1990). Empiricism in Rural Development, Owerri: Karto Press.

- Imo State of Nigeria Official Gazette No 4, 29th October, (2003). Owerri, The Government Printer, 247/1003/500.

- Isiala-Mbano Local Government (2005). IsialaMbano News, Owerri Kramer u/d: 95 Unlagraphics Ltd.

- MPP6 - "Mid- Term review of MPP6" (2006), MPP6 news no 13 March (2008).

- MPP6 - Micro Projects in Six Niger, Annex 4, (2007). Detailed implementation status by State Batches as at 31 March.

- MPP9 - Micro Projects in Nine Niger, (2014). Detailed implementation status by State Batches. 
- Myrdal, g. (1970). The challenge of world poverty, New York, Vintage Books.

- Newsletter (1966). Official publication of the European Community, @publications.europa.eu/index_eu.html

- NewsWatch, How EU Assisted Nigeria before Cooperation Suspension in 1995, December, 4, 1995.

- Niger Delta Development Commission (2006). Niger Delta Regional Development Master Plan - Popular version.

- Nigeria European Union cooperation: Year 2002 Joint Annual Reports.

- Nnabue U.S.F (1990). Illiteracy and rural development. A legal perspective. In Igbozuriuke et a/ (1977). Self-help in the content strategies for rural change and development, Ife, university of Ife.

- Nwaodu, N.O. (2010). Theory and Practice of Development Administration in Nigeria, Owerri, Mega Atlas Projects Ltd.

- Nwaodu, N.O. (2011) International Economic Cooperation: An Introduction to Nigeria's Cooperation with Bi-lateral and Multi-Lateral Donors, Owerri, Mega Atlas Projects Ltd.

- Nweze Amechi (ed.) (1988). Perspective on community and Rural Development in Nigeria. Centre for Development Studies, University of Jos.

- ODC (Overseas Development Council), (1992). Humanitarian intervention in a new world order, ODC, Washington, DC, USA. Policy Focus Series, No.1.

- Offiong D. A. (1980). Imperialism and dependency, obstacles to African development, Enugu, Fourth Dimension Publishing Co.

- Ogunlela v. B and Ogungbile A. O. (2006), Alleviating rural poverty in Nigeria. A challenge for the National Agricultural Research system, vbogunlela@yahoo.com

- Ogunna, A. E. C. (1999), Public Administration in Nigeria Theory and Practice, Owerri: Great Versatile Publishers Ltd.

- Olowu, C.A.B. (1996). "Bureaucracy and the people: The Nigerian Experience" An Inaugural Lecture III, Obafemi AwolowoUniversity, Ile Ife, $6^{\text {th }}$ January (Tuesday).

- Olusola, S and Onwuka R.I. (1997). Nigeria-Africa and the European Union, Beyond 2000, Ibadan, Dokan Publishing House, 1997.

- Ong'wen (2007, EU-ACP partnership and the Kenyan development, 
- Onwuka R. I. (1991). The anguish of dependent regionalism Africa, Ife, Obafemi Awolowo University Press 1991.

- Partnership Agreement between the members of the African, Caribbean and Pacific group of states, and the European Community and its member states, signed in Cotonou, 2000, Benin Republic. 23 June

- Rostow, W.W. (1971). Politics and the stages of growth. Cambridge University Press, Cambridge, UK.

- Rodney W., (1972). How Europe Underdeveloped Africa, London, Eougle -L' Overture Publications.

- Sowole J. (2007). "EU Executes N542m Micro-Projects" ThisDay Online, thisdayonline.com/nview.php?id (06.07.2007).

- The Marshall Plan (1947). The Marshall Plan. Retrieved on $4^{\text {th }}$ July 2006 from http://en.wikipedia.org/wiki/marshallplan.

- The Point, (2000). "From Lome iv to Cotonou," Bulletin of the Institute of Economic Affairs, August.

- The Tide Online (Wednesday April 30, 2008). "EU spends N7bn on Micro-projects in N" Delta."

- Thisday on line/Nigeria news/Africa views on global newswww.thisdayonline.com/nview.php/

- Thrilwall A. P (1994) Growth and development with special references to developing economics, London, Macmillan

- Timamy M.H.K. (2007). The Political Economy of Technological Underdevelopment in Africa; Renaissance Prospects, Global Tyranny, and Organized Spoilation. Lagos, Centre for Black African Arts and Civilization.

- Todara, M. P. (1997). Economics for Developing World. London: Longman.

- Turner M and Hulme D (1997) Governance, Administration and Development, Making the state work, New York, Palgrave.

- Twitchett C. C, (1981). A Framework for Development the EEC and the ACP, London George Allen and Unwin Ltd.

- Uweche R. (ed.), (1981). African Year Book and Who's who, London, Africa Journal Ltd.

- World Bank (1978-1996) the world bank reports, oxford, oxford university press 
- World Bank Report (1989) African adjustment and growth in the 1980's_Washington.Zed Books, London and New Jersey.

\section{AUTHORS' CONTACT:}

\begin{tabular}{|r|l|}
$\begin{array}{r}\text { NWAODU, Nnamdi 0. } \\
\text { Igbinedion University Okada } \\
\text { Edo State, Nigeria }\end{array}$ & $\begin{array}{l}\text { EMMA-EGBUMOKEI, Ngozi Stella } \\
\text { Igbinedion University Okada } \\
\text { Edo State, Nigeria } \\
\text { Email: }\end{array}$ \\
$\begin{array}{r}\text { Email: nwaodunnamdi@yahoo.com } \\
\text { ODEY, Stephen Adi } \\
\text { Department of Sociology, } \\
\text { University of Calabar }\end{array}$ & \\
Email: Steveodey2009@yahoo.com & \\
\hline
\end{tabular}

